\title{
NOTE
}

\section{A third case of amelia in Morelet's crocodile from the Yucatan Peninsula}

\author{
Pierre Charruau ${ }^{1, *}$, Carlos A. Niño-Torres ${ }^{2}$ \\ ${ }^{1}$ Centro del Cambio Global y la Sustentabilidad en el Sureste, A.C., C.P. 86080, Villahermosa, Tabasco, Mexico \\ ${ }^{2}$ Universidad de Quintana Roo, C.P. 77019 Chetumal, Quintana Roo, Mexico
}

\begin{abstract}
Congenital defects in crocodilians have received little interest. In the context of global change and increasing threats to biodiversity, data on birth defects occurring in wildlife could be of importance for estimating the health of species populations and their ecosystems. Herein, we report the first case of amelia (i.e. absence of limbs) in Morelet's crocodiles Crocodylus moreletii from Mexico and the third on the southern Yucatan Peninsula. The crocodile in question was a juvenile (41 cm total length) captured in July 2012 in the Río Hondo, the river that forms the border between Mexico and Belize south of the state of Quintana Roo. The prevalence of this malformation in the C. moreletii population of Río Hondo $(0.35 \%)$ is similar to that reported in 2 previous cases in Belize. Several causes of birth defects in crocodilians have previously been cited in the literature. Although we do not have relevant information to elucidate this case, we discuss some plausible explanations for this birth defect.
\end{abstract}

KEY WORDS: Congenital defect · Crocodiles - Crocodylus moreletii - Ectromelia · Mexico · Quintana Roo

Resale or republication not permitted without written consent of the publisher

\section{INTRODUCTION}

Congenital defects in crocodilians have received little interest and have been more likely to be considered mere curiosities rather than of ecological importance. However, in the context of global change, with an increasing number and intensity of threats to biodiversity, data on birth defects occurring in wildlife could be of importance for evaluating the health of species populations and their ecosystems. In crocodilians, several cases of congenital abnormalities of limbs have been reported in different species (Ferguson 1985, Foggin 1987, Huchzermeyer 2003). Malformations include extra digits (polydactyly), absence of digits (ectrodactyly), reduced digits (microdactyly), fusion of digits (syndactyly), extra limbs (polymelia), absence of limbs (amelia) and reduced limbs (micromelia) (Table 1). However, most of these reports are from captive individuals, and few observations have been recorded in the wild (Table 1). This is likely due to the early death of malformed embryos and neonates and to the low percentage of individuals affected, which reduce their encounter rate (Huchzermeyer 2003). Furthermore, loss of extremities is common in crocodilian populations, especially in dense populations (Seijas 2007), which can make the detection of birth defects difficult. Herein, we report the first case of amelia in crocodilians of Mexico and the third in Crocodylus moreletii in the southern Yucatan Peninsula. We also discuss possible causes of limb agenesis.

\section{CASE REPORT}

Crocodylus moreletii (Morelet's crocodile) is a medium-sized freshwater species distributed in the Atlantic and Caribbean lowlands of Mexico, in Belize 
Table 1. List of limb and digit defects reported in crocodilians. W: wild; C: captive; (-) no information

\begin{tabular}{|c|c|c|c|}
\hline Type of malformation & Species & $\mathrm{W} / \mathrm{C}$ & References \\
\hline Polymelia & $\begin{array}{l}\text { Alligator mississippiensis } \\
\text { Crocodylus niloticus } \\
\text { Crocodylus sp. }\end{array}$ & $\begin{array}{l}\mathrm{C} \\
\mathrm{C} \\
\mathrm{C}\end{array}$ & $\begin{array}{l}\text { Ferguson }(1985,1989) \\
\text { Huchzermeyer (2003) } \\
\text { Youngprapakorn et al. (1994) }\end{array}$ \\
\hline Amelia & $\begin{array}{l}\text { Crocodylus moreletii } \\
\text { Crocodylus sp. } \\
\text { Caiman } \text { sp. }^{\mathrm{a}}\end{array}$ & $\begin{array}{l}\mathrm{W} \\
\mathrm{C} \\
\mathrm{C}\end{array}$ & $\begin{array}{l}\text { Rainwater et al. (1999), this study } \\
\text { Youngprapakorn et al. (1994) } \\
\text { Troiano \& Román (1996) }\end{array}$ \\
\hline Micromelia & Crocodylus sp. & $\mathrm{C}$ & Youngprapakorn et al. (1994) \\
\hline Polydactyly & $\begin{array}{l}\text { Alligator mississippiensis } \\
\text { Alligator mississippiensis } \\
\text { Crocodylus porosus } \\
\text { Crocodylus johnsoni } \\
\text { Crocodylus niloticus } \\
\text { Crocodylus sp. }\end{array}$ & $\begin{array}{l}\mathrm{W} \\
\mathrm{C} \\
- \\
- \\
\mathrm{C} \\
\mathrm{C}\end{array}$ & $\begin{array}{l}\text { Giles (1948) } \\
\text { Ferguson }(1981,1982)^{\mathrm{b}} \\
\text { Deraniyagala }(1936,1939)^{\mathrm{b}} \\
\text { Ferguson (1985) } \\
\text { Huchzermeyer (2003) } \\
\text { Youngprapakorn et al. (1994) }\end{array}$ \\
\hline Ectrodactyly & $\begin{array}{l}\text { Alligator mississippiensis } \\
\text { Crocodylus niloticus } \\
\text { Crocodylus acutus }\end{array}$ & $\begin{array}{l}\mathrm{C} \\
\mathrm{W}\end{array}$ & $\begin{array}{l}\text { Ferguson }(1982)^{\mathrm{b}} \\
\text { Ferguson }(1985) \\
\text { Charruau }(2010)\end{array}$ \\
\hline Syndactyly & $\begin{array}{l}\text { Alligator mississippiensis } \\
\text { Crocodylus sp. } \\
\text { Crocodylus niloticus }\end{array}$ & $\begin{array}{l}\mathrm{C} \\
\mathrm{C} \\
\mathrm{C}\end{array}$ & $\begin{array}{l}\text { Ferguson (1985) } \\
\text { Youngprapakorn et al. (1994) } \\
\text { Huchzermeyer (2003) }\end{array}$ \\
\hline Microdactyly & Crocodylus acutus & $\mathrm{W}$ & Charruau (2010) \\
\hline Not specified & Crocodylus niloticus & $\mathrm{C}$ & Foggin (1987) \\
\hline
\end{tabular}

and in northern Guatemala (Platt et al. 2010). The species is currently listed as 'Lower risk, conservation dependent' by the International Union for the Conservation of Nature and Natural Resources (IUCN) and in Appendix II of the Convention on International Trade of Endangered Species of Flora and Fauna (CITES) for Mexico (Platt et al. 2010). In Mexico, C. moreletii is considered as a 'species subject to special protection' (Diario Oficial de la Federación 2010). Río Hondo is a relatively deep river (mean depth of about $8 \mathrm{~m}$ ) that forms the border between Mexico and Belize. The river houses a relatively high number of $C$. moreletii, with individuals of all size classes and encounter rates that range from 1.72 to 4.70 crocodiles $\mathrm{km}^{-1}$ (Cedeño-Vázquez et al. 2006).

During a crocodile survey in the Río Hondo, Quintana Roo, Mexico, on July 17, 2012, we captured a yearling individual (total length: $41 \mathrm{~cm}$; snout-vent length: $20 \mathrm{~cm}$; mass: $132 \mathrm{~g}$ ) which was missing its left forelimb (Fig. 1). There was no evidence of scarring or other disfigurement to indicate that limb absence was caused by mutilation. Radiography revealed that the bones of the shoulder (coracoid and scapula) were also absent (Fig. 2). The crocodile was marked and released at the site of capture.

Crocodiles with missing parts of extremities have been previously captured. In all these cases, evident

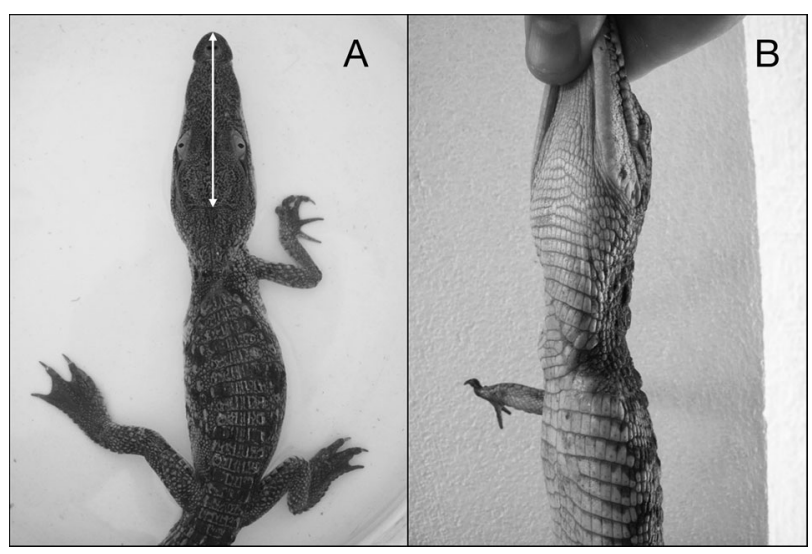

Fig. 1. Malformed crocodile Crocodylus moreletii captured in Río Hondo, Quintana Roo, Mexico. Note the missing left forelimb. (A) Dorsal view; white arrow $=66 \mathrm{~mm}$. (B) Side (lateral) view (photography by Pierre Charruau and Magdalena Hernández Chávez)

scar marks resulting from mutilations during inter- or intra-specific interactions were easily observable. However, in the present case, the entire limb was missing, including the coracoid and scapula bones, and such mutilation would have left evident scars on the skin. These observations indicate that the absence of the limb is likely to be due to agenesis and 


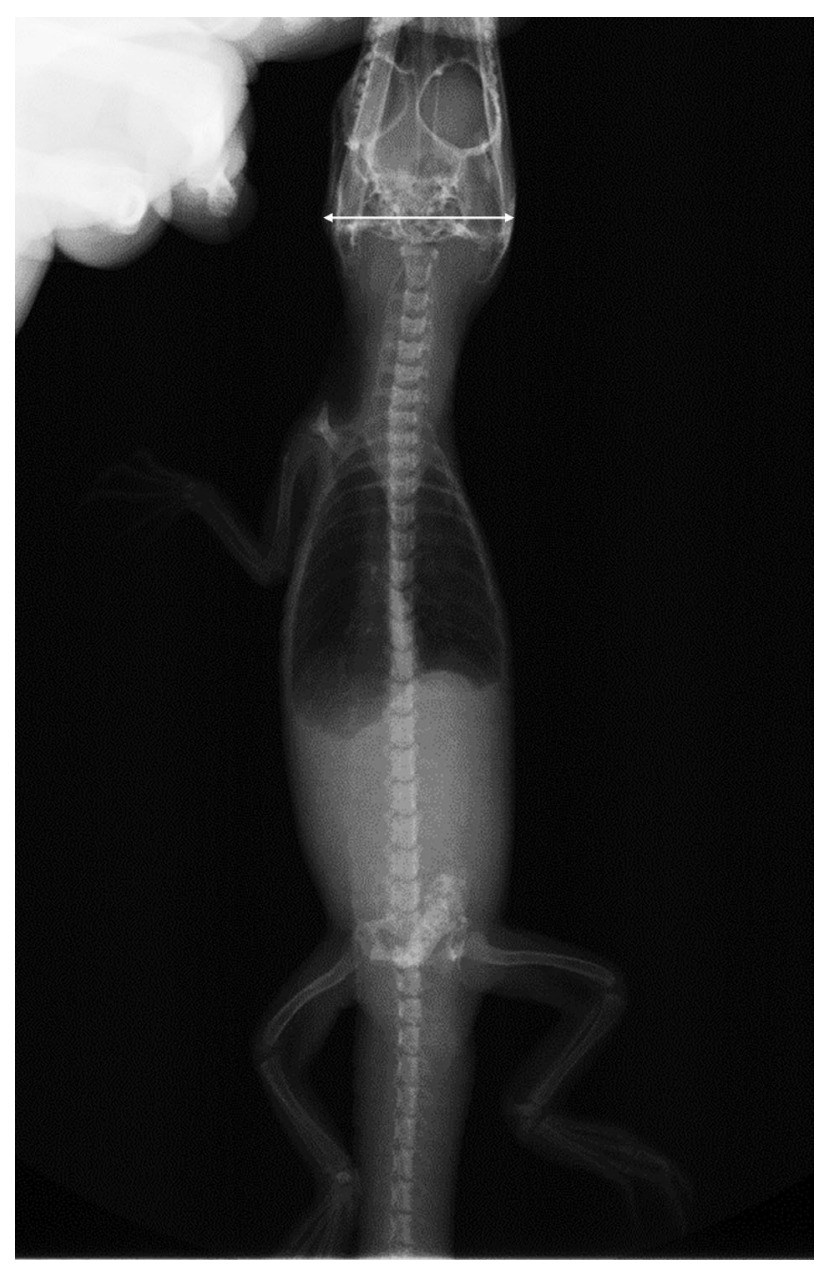

Fig. 2. Radiograph plate of the malformed crocodile Crocodylus moreletii captured in Río Hondo, Quintana Roo, Mexico. Note the absence of the shoulder bones (i.e. coracoid and scapula). White arrow $=30.7 \mathrm{~mm}$

not mutilation. This case is the first report of forelimb agenesis in crocodilians in Mexico and the third case in C. moreletii in the southern Yucatan Peninsula after those reported in Belize by Rainwater et al. (1999). This is the first observation of such an abnormality among the 286 individuals of $C$. moreletii captured in Río Hondo to date (J. R. Cedeño-Vázquez pers. comm.). Our prevalence rate $(0.35 \%)$ is similar to that reported by Rainwater et al. (1999) (0.31\%).

\section{POSSIBLE CAUSES OF AGENESIS}

The different factors associated with congenital deformities in crocodilians have been discussed by Ferguson $(1985,1989)$ and include the age of reproductive females, malnutrition of breeding animals, extremes in incubation temperatures, abnormalities in the hydric or gaseous incubation environment, variation in the orientation of eggs, and exposure to teratogens (such as organochlorine [OC] compounds). Furthermore, a genetic cause could also be considered (Huchzermeyer 2003). As we do not have relevant information to help us elucidate this case, we discuss some plausible explanations.

A young/old mother. Ferguson (1985) reported that Alligator mississippiensis embryos produced by young $(<15 \mathrm{yr})$ and old (>30 yr) females exhibit a higher percentage of spontaneous malformations. Unfortunately, we do not know the age of the mother and we thus cannot conclude that this factor is responsible for the amelia case reported here.

A poor diet. Ferguson (1989) reported that A. mississippiensis females fed on a diet rich in fish are more likely to produce malformed embryos than females fed a diet rich in red meat. Although the diet pattern of the mother of the malformed crocodile is unknown, we discard this possibility. Studies on the diet of Crocodylus moreletii from Northern Belize (relatively near to the capture zone) have shown that although fish are an important part of the diet of adult crocodiles, they principally consume gastropods and other prey items such as insects, crustaceans, reptiles, birds and mammals (Platt et al. 2006). Río Hondo presents all this prey diversity (Espinoza Ávalos et al. 2009).

Anomaly in incubation conditions. It has been documented that anomalies in some incubation conditions (i.e. temperature, humidity, gas exchange, egg orientation) promote malformations in crocodilian embryos (Ferguson 1985, 1989, Webb \& Manolis 1998). C. moreletii is a mound-nesting species that uses vegetation, soil and leaf litter to form a mound in which the female deposits the eggs (Platt et al. 2008). The nest type and nest-site choice generally provides a good and stable level of incubation conditions that buffer the effect of external factors (e.g. environmental temperature, rain, storms) (Magnusson 1979). Once again, in our case we do not know the thermal conditions during the incubation period that may have played a role in the development of the malformed yearling. However, the mean hatching date of $C$. moreletii in the study area is mid-September (Platt et al. 2008), and based on the total length of the yearling (i.e. $41 \mathrm{~cm}$ ), it likely hatched in September 2011. Only 2 tropical storms occurred in the region in 2011, and they occurred after hatching or during the last stages of embryo development. Thus, tropical storms, causing sudden temperature fluctuations, are unlikely to be related to the amelia of the yearling, as 
this defect originates at a very early developmental stage of the embryo. It is impossible to know the orientation of the egg of the malformed yearling during incubation.

Exposure to teratogenic compounds. Raynaud (1990) demonstrated that exposure of embryos to some chemicals induce limb deformities in reptiles. Furthermore, higher rates of thyroid dysfunction, hatching success, egg shell thinning, and gross birth deformities in numerous wildlife populations across the world have been related to habitat contamination (Hamlin \& Guillette 2010). In crocodilians, several birth defects related to endocrine system disruption have been observed in a wild population of $A$. mississippiensis inhabiting a contaminated lake (Guillette \& Milnes 2001, Sepúlveda et al. 2006). However, no direct relationships between the high level of contaminants and deformities have been proved. Crocodilians are a top predator, and due to their elevated position in the food web they bioaccumulate and biomagnify high concentrations of adverse chemicals (Guillette \& Milnes 2001, Campbell 2003, GonzalezJauregui et al. 2012). Organochlorine pesticides (OCPs) are used in agriculture and disease vector control in the region (Álvarez-Legorreta 2009). Furthermore, heavy metals and OCPs have been detected in eggs and scutes of crocodilians near the study area (Wu et al. 2000a,b, 2006, Rainwater et al. 2002, 2007, Charruau et al. 2013). Therefore, contamination could be a cause of amelia in the yearling C. moreletii.

Genetic cause. A last cause of amelia could be the presence of a mutated deleterious allele in parents of the neonate (Huchzermeyer 2003). Deleterious alleles may be recessive and remain inapparent until the mating of individuals carrying the same mutated allele. These recessive deleterious alleles occur at frequencies of less than $1 \%$ (Frankham et al. 2005) and have been suspected to occur in a wild population of gharial Gavialis gangeticus (Huchzermeyer 2003). The low prevalence of amelia reported in this study $(0.35 \%)$ and in Belize $(0.31 \%)$ could support the hypothesis of the existence of a deleterious allele in the populations of $C$. moreletii in the southern Yucatan Peninsula. Mutations occur naturally (Frankham et al. 2005) but can also be induced by environmental factors such as OCs that damage the DNA (deoxyribonucleic acid) of individuals (Novillo et al. 2005). In humans, cases of amelia are very rare and often linked to genetic causes (Niemann et al. 2004, Al Riyami et al. 2012). This is the most likely factor involved in our case of amelia in C. moreletii.

\section{CONCLUSION}

The absence of the entire left forelimb, including the shoulder bones, in the captured yearling crocodile in Río Hondo, together with the absence of clear mutilation marks, indicate a likely third case of amelia in Crocodylus moreletii in the southern Yucatan Peninsula. Although several factors can induce amelia, it is very difficult to know which one is responsible for the present case of limb agenesis. The prevalence of malformation is very low and does not represent a threat to the wild population. Although these cases of birth defects are rare and generally considered to be a curiosity, it is important to report them as they could become more frequent in the future due to the increase in factors inducing these defects. We recommend continuing the monitoring of $C$. moreletii in the region and studying the different factors that can induce birth defects in crocodiles, especially incubation conditions and contamination.

Acknowledgements. We thank A. Escobedo-Galván for his comments on an earlier draft of the manuscript and $\mathrm{M}$. Hernández Chávez for help during the photographic process. The Secretaría de Educación Pública provided support for this project through PROMEP funds. P.C. was awarded a fellowship from the postdoctoral fellowship program of the Universidad Nacional Autónoma de México. All activities were conducted under Mexican law and regulations with a research permit issued by the Secretaría de Medio Ambiente y Recursos Naturales (SEMARNAT) of Mexico (Permit numbers: SGPA/DGVS/03366/12，SGPA/DGVS/10636/11, SGPA/DGVS/03386/12).

\section{LITERATURE CITED}

Al Riyami N, Ahmed A, Tanzeem S, Abdul-Latif M (2012) Fetal amelia: A case report. Oman Med J 27:54-55

Álvarez-Legorreta T (2009) Contaminación acuática. In: Espinoza Ávalos J, Islebe GA, Hernández Arana HA (eds) El sistema ecológico de la Bahía de Chetumal/ Corozal: costa occidental del Mar Caribe. El Colegio de la Frontera Sur, Chetumal, p 205-217

Campbell KR (2003) Ecotoxicology of crocodilians. Appl Herpetol 1:45-163

Cedeño-Vázquez JR, Ross JP, Calmé S (2006) Population status and distribution of Crocodylus acutus and C. moreletii in southeastern Quintana Roo, Mexico. Herpetol Nat Hist 10:53-66

Charruau P (2010) Ecología y etología de anidación del cocodrilo americano (Crocodylus acutus): un estudio para su conservación. PhD thesis, El Colegio de la Frontera Sur, Chetumal

Charruau P, Hénaut Y, Álvarez-Legorreta T (2013) Organochlorine pesticides in nest substratum and infertile eggs of American crocodiles (Reptilia, Crocodylidae) in a Mexican Caribbean atoll. Caribb J Sci 47:1-12

Diario Oficial de la Federación (2010) Norma Oficial Mexicana NOM-O59-SEMARNAT-2010, Protección ambien- 
tal. Especies nativas de México de flora y fauna silvestres. Categorías de riesgo y especificaciones para su inclusión, exclusión o cambio. Lista de especies en riesgo. Órgano del Gobierno Constitucional de los Estados, Gobierno Federal, Secretaria de Medio Ambiente y Recursos Naturales, México, D.F. Segunda sección, jueves 30 de diciembre. Tomo DCLXXXVII 23:1-78

Espinoza Ávalos J, Islebe GA, Hernández Arana HA (eds) (2009) El sistema ecológico de la Bahía de Chetumal/ Corozal: costa occidental del Mar Caribe. El Colegio de la Frontera Sur, Chetumal

Ferguson MWJ (1985) Reproductive biology and embryology of the crocodilians. In: Gans G, Billet F, Maderson PFA (eds) Biology of the reptilian. John Wiley \& Sons, New York, NY, p 329-481

Ferguson MWJ (1989) Birth defects in American alligators. In: Ross CA, Garnett S (eds) Crocodiles and alligators. Facts on File, New York, NY, p 98

Foggin CM (1987) Diseases and disease control on crocodile farms in Zimbabwe. In: Webb GJW, Manolis SC, Whitehead PJ (eds) Wildlife management: crocodiles and alligators. Surrey Beatty \& Sons, Sydney, p 351-362

Frankham R, Ballou JD, Briscoe DA (2005) Introduction to conservation genetics. Cambridge University Press, Cambridge

Giles LW (1948) Polydactylism in an alligator. Copeia 1948: 214

> Gonzalez-Jauregui M, Valdespino C, Salame-Méndez A, Aguirre-León G, Rendón-vonOsten J (2012) Persistent organic contaminants and steroid hormones levels in Morelet's crocodiles from the Southern Gulf of Mexico. Arch Environ Contam Toxicol 62:445-454

Guillette LJ Jr, Milnes MR (2001) Recent observations on the reproductive physiology and toxicology of crocodilians. In: Grigg GC, Seebacher F, Franklin CE (eds) Crocodilian biology and evolution. Surrey Beatty \& Sons, Chipping Norton, p 199-213

- Hamlin HJ, Guillette LJ Jr (2010) Birth defects in wildlife: the role of environmental contaminants as inducers of reproductive and developmental dysfunction. Syst Biol Reprod Med 56:113-121

Huchzermeyer FW (2003) Crocodiles biology, husbandry and diseases. CABI Publishing, Cambridge, MA

Magnusson WE (1979) Maintenance of temperature of crocodile nests (Reptilia, Crocodilidae). J Herpetol 13: 439-443

Niemann S, Zhao C, Pascu F, Stahl U and others (2004) Homozygous WNT3 mutation causes tetra-amelia in a large consanguineous family. Am J Hum Genet 74: 558-563

Novillo A, Kitana N, Marquez E, Callard IP (2005) Reptilian genotoxicity. In: Gardner SC, Oberdörster E (eds) Toxicology of reptiles. Taylor \& Francis, Boca Raton, FL, p 241-266

Editorial responsibility: Alex Hyatt, Geelong, Victoria, Australia
Platt SG, Rainwater TR, Finger AG, Thorbjarnarson JB, Anderson TA, McMurry ST (2006) Food habits, ontogenetic dietary partitioning and observations of foraging behavior of Morelet's crocodile (Crocodylus moreletii) in Northern Belize. Herpetol J 16:281-290

Platt SG, Rainwater TR, Thorbjarnarson JB, McMurry ST (2008) Reproductive dynamics of a tropical freshwater crocodilian: Morelet's crocodile in northern Belize. J Zool 275:177-189

Platt SG, Sigler L, Rainwater TR (2010) Morelet's crocodile Crocodylus moreletii. In: Manolis SC, Stevenson C (eds) Crocodiles. Status survey and conservation action plan, 3rd edn. Crocodile Specialist Group, Darwin, p 79-83

Rainwater TR, McMurry ST, Platt SG (1999) Ectromelia in Morelet's crocodile from Belize. J Wildl Dis 35:125-129

Rainwater TR, Adair BM, Platt SG, Anderson TA, Cobb GP, McMurry ST (2002) Mercury in Morelet's crocodile eggs from northern Belize. Arch Environ Contam Toxicol 42: 319-324

Rainwater TR, Wu TH, Finger AG, Cañas JE and others (2007) Metals and organochlorine pesticides in caudal scutes of crocodiles from Belize and Costa Rica. Sci Total Environ 373:146-156

Raynaud A (1990) Developmental mechanism involved in the embryonic reduction of limbs in reptiles. Int $\mathrm{J}$ Dev Biol 34:233-243

Seijas A (2007) Heridas y parásitos en cocodrilos del Orinoco (Crocodylus intermedius) en un río altamente impactado por actividades humanas. Interciencia 32:56-60

Sepúlveda MS, Del Piero F, Wiebe JJ, Rauschenberger HR, Gross TS (2006) Necropsy findings in American alligator late-stage embryos and hatchlings from Northcentral Florida Lakes contaminated with organochlorine pesticides. J Wildl Dis 42:56-73

Troiano JC, Román L (1996) Diseases encountered in genus Caiman intensive breeding. In: Crocodiles, Proc $13^{\text {th }}$ Working Meeting of the Crocodile Specialist Group. IUCN, Gland, p 328-333

Webb G, Manolis C (1998) Australian crocodiles, a natural history. New Holland Publishers, Sydney

- Wu TH, Rainwater TR, Platt SG, McMurry ST, Anderson TA (2000a) DDE in eggs of two crocodile species from Belize. J Agric Food Chem 48:6416-6420

Wu TH, Rainwater TR, Platt SG, McMurry ST, Anderson TA (2000b) Organochlorine contaminants in Morelet's crocodile (Crocodylus moreletii) eggs from Belize. Chemosphere 40:671-678

- Wu TH, Cañas JE, Rainwater TR, Platt SG, McMurry ST, Anderson TA (2006) Organochlorine contaminants in complete clutches of Morelet's crocodile (Crocodylus moreletii) eggs from Belize. Environ Pollut 144:151-157

Youngprapakorn P, Ousavaplangchai L, Kanchanapangka S (1994) A colour atlas of diseases of the crocodile. Style Creative House, Bangkok

Submitted: September 30, 2013; Accepted: March 12, 2014 Proofs received from author(s): May 8, 2014 